\title{
The Impact of a Digital Educational Story Based on Sports on Developing Alphabetical Learning Skills among Jordanian Pre-School Kids in Light of the Covid-19 Pandemic
}

\author{
Hussien H. Almistareehi ${ }^{1}$ \& Nashwan A. Nashwan ${ }^{2}$ \\ ${ }^{1}$ School of Educational Sciences, Isra University, Jordan \\ ${ }^{2}$ School of Arts, Isra University, Jordan \\ Correspondence: Hussien H. Almistareehi, School of Educational Sciences, Isra University, Jordan.
}

Received: February 20, 2021

Accepted: March 19, 2021

Online Published: March 30, 2021

doi:10.5539/mas.v15n2p96

URL: https://doi.org/10.5539/mas.v15n2p96

\begin{abstract}
This study aimed to identify the impact of a digital educational story based on sports on developing alphabetical learning skills among Jordanian pre-school kids in light of the Covid-19 pandemic. The study sample consisted of (29) pre-school kids from the leaders' international schools, "The International Curriculum," which is affiliated to Al-Qweismeh District's Directorate in Amman. The study used an Experimental approach; the study sample chosen by intention randomly was divided into two groups: experimental group (14) kids: (7) girls and (7) boys, and control group (15) kids: (7) are boys, and (8) are girls. To achieve the study's goal, the researchers built a guide for the teacher to implement the experiment; they also built a pre-and post-test consisting of (16) items and provided the Arabic language teacher with digital educational stories based on sport learning the alphabet. The stories include the alphabet lessons: (letter al-ba, letter al-da, letter al-ha, letter al-ain), from the "curriculum in the Arabic language" for the academic year 2020/2021. The results of the study showed that there were statistically significant differences in favor of students of the experimental group, which studied the digital educational story in each Alphabet learning skills: Pronunciation, Abstraction, and writing, in the combined skills, and the absence of statistically significant differences attributed to gender, interaction in testing the skills of learning the alphabet together, and in each of the skills of learning the alphabets: (pronunciation, abstraction, writing). In light of the findings mentioned above, the researchers proposed a set of recommendations that include Arabic language curricula guides in digital educational programs based on sports to be used in learning and teaching processes in teaching Arabic.
\end{abstract}

Keywords: digital educational story, sports, alphabet learning skills, pre-school kids, Covid-19 pandemic

\section{Introduction}

Learning the alphabet in the early childhood stage is characterized by the ability to produce language; Words are reproduced from letters, and sentences are formed from words; the child acquires the skill of learning the alphabet by pronouncing it with the accompanying movements and writing it with the correct spelling. This leads to vocabulary learning and increased linguistic wealth; Thus, it leads to language production: conversation, writing, and its application in everyday life.

Human beings learn the language in the prime of his childhood by mediating the environment in which he lives, including his parents' influence by listening to the phraseology and vocabulary (Zahran \& Taaima, 2009), the child expresses his needs in the language of sign and screaming. Language development is accompanying age growth (Ashour \& Miqdadi, 2005); (Abu Latifa, 2009); Sometimes we find uttering the letters using them to denote words, such as papa, mama, and he does not automatically perform operations related to writing, such as scribbling and coloring.

Among the skills indicating learning the alphabet for pre-school kids: the skills to understand the heard letter, the ability to distinguish it from other letters by hearing, employ the operations resulting from listening to the letter in writing and reading, skills related to the pronunciation of the letter, taking it out correctly, its shape with movements, and its combination with Another letter, and its analysis from a group of letters, including skills related to writing the alphabet, transcription, dictation, structure, and research (Al-Juhani, 2015); (Yaghmour \& Obaidat, 2016). 
There are many methods of teaching alphabets to kids, perhaps the most prominent of which is the total method (from the whole to the part), which is based on displaying the word that contains a specific letter, then determining this letter, and the partial method (from the part to the whole), which is based on displaying the alphabet and linking it By the word, the generative method, which is based on a combination of the two methods: the total and the partial (Souman, 2012; Al-Khatib, 2009), and replicate them en masse.

As a result of the education sector keeping pace with technological developments, modern technology has been employed in the learning process. One of these means is the interactive board through which digital educational stories based on a sport are presented, specifically designed to learn the alphabet in a manner that suits the spirit of the times, achieves learning outcomes with the least time and effort, and works to stabilize learning among pre-school kids. The results of studies indicate a general weakness in learning alphabet skills in pre-school kids. Therefore, this study concluded the impact of digital educational games based on a sport in developing skills learning the alphabet in pre-school kids in light of the Covid-19 pandemic.

\subsection{Purpose of the Study}

The process of learning the alphabet is the basic rule in learning the Arabic language. As the child learns the alphabet elaborately, he Gains the ability to read and write easily and easily; for this, the institutions that deal with the kindergarten "pre-school child" and parents should focus on learning those letters and giving them to the child smoothly and easily. This makes them receptive to preserving them and able to employ them with positive and effective energy.

In light of the above, this study's main problem revolves around determining the impact of a digital educational story based on sports on developing alphabetical learning skills among Jordanian pre-school kids in light of the Covid-19 pandemic.

The current study deals with the "international curriculum," in which learning materials in the English language are often overwhelmed by the Arabic language; this negatively affects the acquisition of writing the alphabet. This is in addition to what the learning sector witnesses during the study period from moving to online learning due to the repercussions of the Covid-19 pandemic and the public safety measures it imposed in terms of staying at home. In addition to the difficulty of dealing with the age group that the researchers chose as a sample for the study, in terms of enhancing and focusing their attention on the educational content they receive from a distance, all this called on researchers to design a guide for employing digital educational stories in learning the alphabet. To reduce the weakness of kindergarten kids in learning alphabet skills, as the results of the study (Abu Jamous \& Kanan, 2008) indicated that there is a weakness in learning language skills and their patterns in the kindergarten stage, this result is consistent with the study (Loniza et al., 2018) which emphasized the existence of weakness in learning the alphabet among pre-school kids.

Thus, the study problem can be identified by the following two questions:

1) Are there statistically significant differences at the level of $(a=0.05)$ in the development of alphabet learning skills among pre-school kids due (to the digital story based on sports, the usual method)?

2) Are there statistically significant differences at the level of $(a=0.05)$ in developing the skills of learning the alphabet among pre-school kids due to gender and interaction"?

\subsection{Significance of the Study}

The importance of the study stems from the results it is expected to yield; its importance can be defined as follows:

1) Inform employees of the Arabic language curricula and methods of teaching it, and those working in the kindergarten field, about the benefits of the digital educational story, based on sports in learning Arabic language skills, especially the skills of learning the alphabet.

2) Enabling pre-school kids to interact positively with each other; through learning the alphabet, its pronunciation, writing, analysis, synthesis, exchange of ideas, learning vocabulary, understanding processes, producing oral material, and employing it in the practical life scale.

3) Keeping up with the change in the teacher's role has evolved from cues to the learning process to a facilitator and supervisor of it, and here the child's role turns from recipient to positive, interactive participant.

4) To attract the kids' attention and stimulate them for the educational lesson, achieving learning objectives and developing active listening habits leads to learning alphabet skills. 
5) It is hoped that this study will benefit researchers in conducting similar studies on other language skills because it is a modern strategy, compatible with the spirit of the times and the twenty-first century's skills.

\subsection{Limits of the Study}

\subsubsection{Spatial Boundaries}

Al-Qada International Schools affiliated to the Education Directorate in Qweismeh District in Jordan.

\subsubsection{Temporal Limits}

The first semester of the academic year 2020/2021, for 6 weeks, at the rate of five lessons per week.

\subsubsection{Human Limits}

29 pre-school kids (pre-school stage) were chosen by the intentional method and divided into two experimental and control groups.

\section{Literature Review}

The language learning process is an accelerated process under the means of technology in the era of the cognitive explosion, where the human being can complete the linguistic learning processes; If he has the appropriate capabilities, and perhaps technology is one of these capabilities that contribute to improving the linguistic precedence of young people.

The researchers believe that the learning process in digital educational programs is one of the linguistic learning methods through which the teacher provides all the conditions and capabilities of educational images accompanied by movement, toning the sound, and coloring it in proportion to the educational position. To achieve learning goals, kids practice the oral and written summarization processes of the digital educational program and interact with them by linking each mathematical movement with the letter to be learned.

The digital educational story is defined as: "A new style of presenting stories to kids at different ages that kids enjoy, that works to attract their attention, excite them, and make them listen for a long time, with multiple goals" (Abu Afifa, 2016:31), (Miller, 2015:42) defined the digital educational story as "a short personal story that is told through multimedia, such as images, sound, and accompanying effects, and seeks to achieve meaningful and diverse educational goals."

Linking the digital educational story to sports can be justified to the fact that movement is one of the activities most related to the child; movement and play are the nature and basic needs of the child at this age. The use of movement in the framework of play as a comprehensive educational method has begun more suitable for this stage than any other stage of age, which at the same time helps a safe transition from kindergarten. With its recreational games. To the first episode of basic education (Lee, 2014; Zankour, 2017).

Childhood is the period of real and fundamental construction of an individual's personality; Child rearing is the most important stage in the education stages. This parenting process includes many things such as: For the child to be able to join the society around him, to have a distinct, independent personality with its own characteristics, and to gain talents and abilities that must be developed.

Unfortunately, raising kids in Arab countries, in particular, takes a traditional form. Kids lose their true abilities and talents, which are supposed to be developed from a very early age. This is due to the increase in the number of kids in a single-family; the mother may be a worker or non-working woman, as she does not give her kids a full right to discover themselves, the father also does not participate in the process of raising his kids.

This wrong upbringing is either due to poor parenting skills, lack of proper scientific experience to raise kids, develop their abilities, and discover their skills, or because there is some experience, the reasons, and excuse for not having time to devote themselves to such matters for kids, and considering that such things are secondary and not of Essential things for raising a child.

Each child should be given enough time to deal with; this aspect makes the parents and teachers able to discover things that the child loves, the type of games, the colors he is most attracted to, and the type of music that he is attracted to.

Digital educational stories based on sport in their various forms contribute to presenting patterns, linguistic structures, vocabulary, and speech in meaningful contexts that support language comprehension skills (Al-Mestarihi, 2013). In language teaching; because includes the presence of artistic elements and an expressive storyboard, it helps in motivating kids in the processes of language learning, improving the skill of listening, and making teaching a more effective language (Shelton \& Hale, 2017). 
The digital educational story's importance is mainly shown to attract kids' attention to the lessons; it helps to inculcate values and trends by representing the dynamic, effective situations presented in the digital educational story (Yamac \& Ulusoy, 2016). It also contributes to the formation of feelings. The love between teacher and her/his students; Which drives their learning process; The stories contain an element of suspense and excitement (Abu Afifa, 2016), these stories work to establish learning in kids, and not to forget information, facts, and opinions easily Because it works on the positive interaction of learning with the elements of sound and image with appropriate storytelling (Hett, 2012), and helps to increase the positive participation of kids in the lesson, by means of asking different questions, and interacting with the contents of the digital story and its events.

The importance of digital educational stories in relation to the Arabic language (skills, systems) can be identified in that they contribute to increasing kids' language skills when they hear words, their sounds, and their proper pronunciation. It increases their vocabulary and linguistic structures, accustoms them to the correct pronunciation and spelling method (Abu Afifa, 2016), and facilitates learning to read and write for kids. They can link the symbols printed on the pages, the words they listen to and see through the digital story; they work to attract kids' attention to educational lessons related to the alphabet and improve the language learning processes related to the alphabet in speaking and writing.

The purpose of employing the digital educational story in this study is to develop language proficiency skills related to alphabet learning among pre-school kids, including training kids in processes of language communication with others, developing effective listening through the habits of the digital educational story, and developing positive attitudes towards mastery Language proficiency skills, and the ability of kids to practice oral summarization of the digital educational story.

The researchers reviewed the studies that dealt with the effect of the digital story on the acquisition of learning skills in general; these studies were presented from the most recent to the oldest as follows:

Loniza et al., 2018 conducted a study aimed at identifying "the effect of digital stories on developing listening comprehension skills in early childhood stage," the study sample consisted of (27) kids, who were chosen by the intentional method, they were divided into two groups: an experimental one. Teaching in it by means of digital stories and control, in which the teaching was done by the traditional method, the researchers applied the pre-post test to the two study groups before starting the implementation of the study, after completing it, the results revealed that the experimental group got a very high score, with statistically significant differences in improving Audible comprehension skills in the aspect of language learning at the expense of the control group.

Abu Sakran, 2017 built a proposed program based on movement strength to measure its effectiveness in academic achievement and to develop mathematical communication and thinking skills among the tenth-grade students in Gaza City, Palestine. The researcher used the experimental approach based on one group; he prepared the educational program and the test achievement test's measuring tools, divergent thinking test, and mathematical communication test.

Al-Kitabi, applied an educational story to a sample of tenth graders, consisting of (30) female students; the study concluded the effectiveness of the existing educational program on the mathematical strength in developing knowledge acquisition, improving skills, and divergent thinking at a high degree.

Abu Afifa, 2016 conducted a study to investigate the digital story's impact on developing the active listening skills and creative thinking of third-grade students in the basic Arabic language subject. The researcher chose an intentional random sample, consisting of (36) students from the third-grade students, distributed among two popular schools of the International Pioneer Academy "International Curriculum," in two groups: experimental, numbering (19) male and female students, which were taught With the strategy of the digital story, and a control group of (17) male and female students, which was taught in the usual way, the results showed that there was a difference of statistical significance on the post-listening test in the Arabic language subject. For the benefit of the experimental group students, there is no difference in the creative thinking test in the Arabic language in favor of either group.

Yamac \& Ulusoy 2016 conducted a study aimed to measure "the effect of digital storytelling in improving writing skills for third-grade students enrolled in rural primary schools." The study sample consisted of (26) male and female students, of whom (16) were female, and (10) were males, the study adopted the design of procedural research from qualitative research techniques; To reveal how digital storytelling works in teaching writing, and the writing performance of students was measured before and after the teaching procedures for digital storytelling, through field notes, interviews, audio and video records, student notes, and their writing work, the results indicated that digital storytelling enhanced ideas Students' organization, word choice, sentence fluency, writing quality, improving students 'understanding of the elements of the story, and increasing their 
vocabulary from the words contained in it, the results indicated that digital storytelling enhanced students 'ideas, organization, word choice, sentence fluency, quality of writing, improved students' understanding of the elements of the story, and increased their vocabulary from the words contained in it. It raised the students 'efficiency in all educational process stages, and the storytelling modified the narrative writing process, and a useful tool emerged. Digital storytelling has also created an educational community by improving interactions between students in the classroom and increasing their writing motivation.

Al-Areenan 2015 conducted a study to identify "the effectiveness of using electronic stories in developing some language skills: listening and speaking among a kindergarten child." To achieve the objectives of the study, research tools were designed, represented in the list of skills: listening and speaking, a form for evaluating my skills: listening, speaking, electronic stories, and a teacher's guide for using electronic stories. The sample was chosen randomly, which was represented in two groups: the experimental, which numbered (22) kids, and the control, and its number (22) kids. The study found significant differences between the two groups' mean scores: experimental and control, in the post-evaluation. For the benefit of the experimental group in skills: speaking, listening.

The current study benefited from previous studies in building its theoretical framework; this study is distinguished from other previous studies in the following points:

1) This study links the digital educational story with sports by designing a digital story based on sports movements that suit the study sample's age group, and none of the previous studies has ever addressed this topic.

2) The population of the study, which is Jordanian pre-school kids, was not covered by any of the previous studies.

3) The educational digital story based on sports will be applied to pre-school students "International Curriculum".

\section{Method and Procedures}

\subsection{Study Approach}

The experimental approach was used by dividing the study sample individuals into two groups: control and experimental groups.

\subsection{Study Sample}

The study sample consisted of (29) pre-school kids from Al-Qaida International Schools, "International Curriculum," affiliated to the Directorate of Education in Qweismeh District. The study sample was chosen by the intentional method, then were divided randomly into two groups: experimental, studied using the digital educational story, and its number reached (14), including (7) kids, (7) girls, and a control group consisted of (15) kids according to the regular teaching method.

Table 1. Distribution of study sample according to the method of teaching and gender

\begin{tabular}{llll}
\hline Teaching method & Gender & Freq. & Percentage \% \\
\hline \multirow{3}{*}{ Regular method } & Male & 7 & $\% 47$ \\
& Female & 8 & $\% 53$ \\
& Total & 15 & $\% 100$ \\
Digital educational story & Male & 7 & $\% 50$ \\
& Female & 7 & $\% 50$ \\
& Total & 14 & $\% 100$ \\
Total & Male & 14 & $\% 48$ \\
& Female & 15 & $\% 52$ \\
& Total & 29 & $\% 100$ \\
\hline
\end{tabular}




\subsection{Study Tools}

The researchers prepared the following tools:

\subsubsection{Test the Skills of Learning the Alphabet}

The researchers prepared a test (pre and post) to measure the degree of ownership of pre-school kids; the skills of learning the alphabet in three main skills: (pronunciation, abstraction, writing), for each skill there are four indicators, the test in its final form consisted of (16) paragraphs, distributed on the skills of learning the alphabet and its indications. A set of procedures in preparing the test, including:

- Review of educational literature and previous studies related to learning alphabet skills, including: (Yamac \& Ulusoy, 2016; Slot, 2010; Al-Ghamdi, 2013).

- Identify the indications related to the skills of learning the alphabet.

According to the associated indicators, build test items according to skills (pronunciation, abstraction, and writing).

- Conducting validity and reliability factors for the test.

\subsubsection{Validity of Alphabet Learning Skills Test}

The two researchers presented the test in its preliminary form to specialists in kindergartens, Arabic language curricula, and methods of teaching it, and to a number of educational supervisors and teachers. Those who teach Arabic to pre-school kids; to express their opinion on the test in terms of its suitability for kids, the safety of its language, the veracity of the information received. Based on the referees' observations, the researchers added paragraphs, deleted some of them, and amended some paragraphs until the test settled on its final form.

\subsubsection{Reliability of the Test}

To verify the study tool's stability, "the test" it was applied to an exploratory sample of the study population from outside the study sample, consisting of (10) kids from AlQadah international schools. The test-retest, with an interval of two weeks between the two applications, then the Pearson correlation coefficient was calculated between their estimates both times, the reliability coefficient was calculated using the internal consistency method (Cronbach Alpha). Table (2) shows the internal consistency coefficient for each skill of learning the alphabet and its degrees, where these values were good and appropriate for this study.

Table 2. Cronbach's alpha, repetition constant for skills, and overall score

\begin{tabular}{lll}
\hline Scope & Constancy of redo & internal consistency \\
\hline Pronunciation & 0.87 & 0.76 \\
Abstraction & 0.90 & 0.79 \\
Writing & 0.89 & 0.77 \\
Total marks & 0.92 & 0.86 \\
\hline
\end{tabular}

\subsubsection{Parameter's Guide in Performing the Experiment}

The researchers prepared a guide that includes theoretical aspects of concepts, terminology, and information related to digital educational stories based on sports, with the skills of learning the alphabet, to deepen the awareness of the Arabic language teacher who was assigned the task of implementing the experiment, following up on the work of pre-school kids, providing appropriate feedback. The guide includes a description of the teacher's procedures before, during, and after the application; It includes the time plan, contents, learning resources, teaching aids, goals, learning strategies, evaluation strategies, and tools.

\subsubsection{Digital Educational Story Based on Sport}

The researchers reviewed the digital educational stories by referring to the sources of knowledge and the Internet. After a process of research, investigation, and consideration of programs and applications specially prepared for teaching the alphabet, they selected four digital educational stories representing the alphabet that the Qatar Education Initiative designed under the title "Siraj." These stories are called after the names of the letters related to the Arabic language curriculum: (the letter Baa, the letter Dal, the letter Haa, and the letter Ayn), they are identical in their design to the Arabic language curriculum of Alqadah International Schools of for the first semester 2021/2021.

The story's events revolve specifically around the alphabet; it includes a group of words related to the alphabet, the method of pronunciation, and correct writing for it. Its events are suitable for kindergarten kids in terms of 
presentation and style as well as the use of movement elements, music, and animation, and the teaching of these stories is applied according to Procedures defined in terms of introduction, presentation, the practice of pronunciation, abstraction, writing, and re-summarization; And that is by following up the Arabic language teacher, supervising and directing her.

The researchers developed a set of major motor skills, such as movement of the arm's muscles, leg, or foot, or movement of the whole body, which includes a group of activities, such as crawling, jogging, and jumping.

The researchers gave each letter a sports movement, the letter al Baa: a light jump, the letter Aldaa: a slight dart, the letter alha'a: a circular run, and the letter alayn: stretching the arm muscles.

\subsubsection{Validity of Parameter's Guide and Digital Educational Story Based on Sport}

The researchers presented the parameters guide and the digital educational story to specialists in kindergarten, Arabic language curricula, several educational supervisors, and Arabic language teachers who teach in kindergarten. To express their views on the parameters guide and digital educational story in terms of the integrity of the language, the validity of the information, the procedure of deleting and addition in proportion to the objectives of the study, the researcher took their observations in relation to the evidence, which related to making some changes (deleting, modification, addition), and conducting accompanying language treatments, and the different types of evaluation Used in the study until the evidence has settled on its final form; As for the digital educational stories, the judges expressed their suitability and suitability for preschoolers without any remarks.

\subsubsection{Procedures of Employing the Digital Educational Story Based on Sport in Learning Alphabet Skills}

Digital educational stories based on sports were implemented via the smart screen, the language-related treatments were carried out by several practices, guidelines, and instructions based on cooperation between the Arabic language teacher and pre-school kids in light of the Covid-19 pandemic, according to the following procedures:

1) Welcoming kids and engaging them in the digital educational story based on sports.

2) The teacher asks the kids to do some light exercises (such as jumping, raising hands) to increase their enthusiasm.

3) The teacher presents the digital educational story based on sport to pre-school kids through an interactive board that is shared through the Teams application.

4) Pre-school kids listen carefully to the digital educational story based on the sport.

5) The teacher supervises the educational story presentations through the Teams app.

6) The teacher pauses the digital sports-based educational story during the presentation; to raise some questions related to the story and teaches kids the sports moves associated with each letter.

7) In cooperation with the kids, the teacher determines the alphabet in the educational story and links it to the relevant words.

8) The teacher uses an interactive board; to perform the correct pronunciation and writing of the semantic letter learning it.

9) The teacher assigns pre-school kids to make sports movements for each letter, express the pictures, positions mentioned in the story, and conduct an oral summary of the audio story.

10) The teacher discusses pre-school kids in the events of the story.

11) Pre-school kids practice active participation in the events on which the digital educational story is based.

12) Pre-school kids listen well to others' comments and opinions, according to the principles of practicing calm and purposeful discussion, adhering to calm, discipline in the classroom, and listening to the teacher's instructions and instructions.

13) The teacher reinforces pre-school kids based on their answers to the questions asked.

14) The teacher specifies for pre-school kids the procedures, linguistic and kinetic tasks associated with learning letters, and what they should implement within the quantitative, qualitative, and time standards. Five classes a week. 
15) Pre-school kids practice the processes related to learning the alphabet, such as: pronouncing the letter, writing the letter, and analyzing and synthesizing words related to the alphabet.

16) According to the specified relevant standards, pre-school kids carry out the assigned tasks according to the allotted time.

17) According to the

18) Tasks assigned to them, the teacher provides feedback to pre-school kids and immediately whenever possible.

19) The teacher summarizes the most important ideas that the kids have come up with through commenting and commenting. And according to what is required by the situation of learning the alphabet and providing appropriate reinforcement, according to the kids' observed behavior.

\subsection{Study Implementation Procedures}

This current study was implemented according to the following procedures:

- Providing digital educational stories based on sports-related to the alphabet; to be displayed by the smart screen; and providing the parameter guide; To carry out the experiment, worksheets, materials, resources, and teaching aids for the experiment pre-school kids in the experimental group.

- To visit the Collaborating Alqada International Schools, explaining the general idea and the philosophy that underpins the study, working to meet the teacher and kids, and talking about digital educational stories and their importance for kids.

- To determine the divisions of Alqadah International Schools "International Curriculum" for pre-school kids of the two groups: experimental and control, and test consistency in trial schools.

- To train the Arabic language teacher who was assigned the task of applying the experiment to the kids of the experimental group in terms of discussing the objectives of the experiment, the teacher's guide for the experiment, the accompanying linguistic procedures, and how to evaluate them through two workshops devoted for this purpose.

- To prepare study tools and conducting validity and reliability transactions for each of them.

- Apply the study tools within the two groups' kids' pre-measurement and calculate the parity between the two groups in testing the skills of learning the alphabet.

- Develop a plan to enable every child to practice learning about digital educational stories via the smart screen and accomplish what is required.

- Follow-up of the experiment by contacting the teacher in the experiment to ensure the experiment's smooth running; To find out the progress of the application process, identify the difficulties that the kids and the teacher's face, and overcome them.

- Apply the post-measurement of the study tools on the experimental and control group kids after completing the experiment and the completion of the accompanying language tasks.

- To process data in light of the study questions and writing a research report.

\section{Results Discussion}

1) First: The results of parity of the two study groups

To verify the two study groups' parity: (experimental and control), the means and standard deviations of pre-school kids' grades in learning the alphabet skills were calculated according to the group, and gender variables Table (3) illustrates this. 
Table 3. Means and standard deviations of the grades of pre-school kids in the skills of learning the alphabet according to the group and gender variables

\begin{tabular}{lllll}
\hline Group & Gender & Mean & STD. & Number \\
\hline Experimental & Male & 33.71 & 4.348 & 7 \\
& Female & 36.43 & 4.541 & 7 \\
& Total & 35.07 & 4.497 & 14 \\
Control group & Male & 35.14 & 2.610 & 7 \\
& Female & 37.25 & 2.605 & 8 \\
\multirow{3}{*}{ Total } & Total & 36.27 & 2.738 & 15 \\
& Male & 34.43 & 3.524 & 14 \\
& Female & 36.87 & 3.523 & 15 \\
& Total & 35.69 & 3.675 & 29
\end{tabular}

Demonstrate the statistically significant differences between these means' averages, the bilateral variance analysis was used, as shown in Table.

Table 4. Binary variance interaction analysis of the group and gender variables on the grades of pre-school kids on learning skills of the alphabet

\begin{tabular}{llllll}
\hline Source of variance & Sum of squares & Degrees of freedom & Average of squares & P-value & Statistical significance \\
\hline the group & 9.145 & 1 & 9.145 & .702 & .410 \\
Sex & 41.993 & 1 & 41.993 & 3.225 & .085 \\
Gender x group & .666 & 1 & .666 & .051 & .823 \\
The error & 325.500 & 25 & 13.020 & & \\
Total & 378.207 & 28 & & & \\
\hline
\end{tabular}

Table (4) shows the following:

There were no statistically significant differences at $(\mathrm{a}=0.05)$ due to the group effect, the effect of sex, and the effect of the interaction between the group and the gender, and this indicates the parity of groups in terms of group and sex and the interaction between them.

2) Second: Results of the study questions

i. First question: "Are there statistically significant differences at the level of $(\alpha=0.05)$ in the development of alphabet learning skills among pre-school kids due to (the digital educational story, the usual method)"?

ii. Second question, which stated: "Are there statistically significant differences at the level of $(\alpha=$ $0.05)$ in the development of alphabet learning skills among pre-school kids due to gender and interaction"?

To answer these two questions, means and standard deviations of the grades of pre-school kids in the skills of learning the alphabet in the pre and post measurements were calculated according to the variables of the teaching method and gender; Table No. (5) shows the results: 
Table 5. Means and standard deviations of the grades of pre-school kids in the skills of learning the alphabet for the pre and post scales according to the group and gender variables

\begin{tabular}{|c|c|c|c|c|c|c|}
\hline \multirow{2}{*}{ Group } & \multirow{2}{*}{ Gender } & \multicolumn{2}{|c|}{ Pretest } & \multicolumn{2}{|c|}{ Post-test } & \multirow{2}{*}{ Number } \\
\hline & & Means & STD. & Means & STD. & \\
\hline \multirow[t]{3}{*}{ Experimental } & Male & 33.71 & 4.348 & 62.57 & 2.878 & 7 \\
\hline & Female & 36.43 & 4.541 & 64.43 & 2.878 & 7 \\
\hline & Total & 35.07 & 4.497 & 63.50 & 2.929 & 14 \\
\hline \multirow[t]{3}{*}{ Control } & Male & 35.14 & 2.610 & 54.43 & 3.780 & 7 \\
\hline & Female & 37.25 & 2.605 & 54.88 & 5.303 & 8 \\
\hline & Total & 36.27 & 2.738 & 54.67 & 4.499 & 15 \\
\hline \multirow[t]{3}{*}{ Total } & Male & 34.43 & 3.524 & 58.50 & 5.317 & 14 \\
\hline & Female & 36.87 & 3.523 & 59.33 & 6.477 & 15 \\
\hline & Total & 35.69 & 3.675 & 58.93 & 5.855 & 29 \\
\hline
\end{tabular}

Table (5) shows the existence of apparent differences between the arithmetic mean of pre-school kids' degrees in learning the alphabet in the pre and post-test according to the two study groups: (experimental, control). To find out whether these apparent differences are statistically significant, the accompanying binary variance (One-way ANCOVA) for the post-measurement of the skills of learning the alphabet as a whole, according to the group (experimental, control) after neutralizing the effect of the pre-measurement they have, the following is a presentation of these results as shown in Table (6):

Table 6. Results of the accompanying binary variance analysis (One-way ANCOVA) for the post-measurement of the grades of pre-school kids in the skills of learning the alphabet according to the group (experimental, control), and the gender and the interaction between them after neutralizing the effect of the pre-measurement they have

\begin{tabular}{lllllll}
\hline $\begin{array}{l}\text { Source of } \\
\text { variance }\end{array}$ & $\begin{array}{l}\text { Sum of } \\
\text { squares }\end{array}$ & $\begin{array}{l}\text { Degrees of } \\
\text { freedom }\end{array}$ & $\begin{array}{l}\text { The average } \\
\text { sum of squares }\end{array}$ & P. Value & $\begin{array}{l}\text { level } \\
\text { denotation }\end{array}$ & $\begin{array}{l}\text { ETA 2Square } \\
\boldsymbol{\eta}^{2}\end{array}$ \\
\hline $\begin{array}{l}\text { Pre-measurement } \\
\text { the group }\end{array}$ & 52.464 & 1 & 52.464 & 3.821 & .062 & .137 \\
Gender & 607.864 & 1 & 607.864 & 44.268 & .000 & .648 \\
Group x gender & .217 & 1 & .217 & .016 & .901 & .001 \\
The error & 2.455 & 1 & 2.455 & .179 & .676 & .007 \\
Macro & 329.554 & 24 & 13.731 & & & \\
\hline
\end{tabular}

It is evident from Table (6) that there are statistically significant differences at the level of significance $(\mathrm{a}=0.05)$ in the degrees of the study sample in alphabet learning skills according to the group (experimental, control), which is a statistically significant value, that means there is a group effect. The modified arithmetic means and standard errors were extracted according to the group to determine in favor of whom the differences were attributed. Table (7) shows that.

Table 7. The adjusted arithmetic means and standard error of grades of pre-school kids in the skills of learning the alphabet according to the group variable

\begin{tabular}{lcc}
\hline Group & Means & STD. \\
\hline Experimental & 63.748 & .998 \\
Control & 54.448 & .965 \\
\hline
\end{tabular}

Results in Table (7) indicate that:

- The differences favored the experimental group exposed to the digital educational story based on sports compared to the control group.

- There were no statistically significant differences at the level $(\mathrm{a}=0.05)$ due to gender, as the $\mathrm{p}$-value was (0.016) and with statistical significance amounted to (0.901). 
- There were no statistically significant differences at the level $(a=0.05)$ due to the interaction between the group and gender, as the p-value was (0.179) and in statistical significance $(0.676)$

- The size of the group's impact was significant: The value of the Eta square explained (64.8\%) of the explained (predicted) variance in the dependent variable, which is the skills of learning the alphabet.

The arithmetic means and standard deviations of the pre and post measurements of the dimensions of the alphabet learning skills were calculated according to the two variables of the group (experimental, control) and gender, as shown in Table (8)

Table 8. The arithmetic means and standard deviations of the grades of pre-school kids in the skills of learning the alphabet for the pre and post scales according to the group variables (experimental, control), and gender

\begin{tabular}{|c|c|c|c|c|c|c|c|}
\hline & \multirow[b]{2}{*}{ Group } & \multirow[b]{2}{*}{ Gender } & \multicolumn{2}{|c|}{ Pretest } & \multicolumn{2}{|c|}{ Pose- test } & \multirow{2}{*}{ Number } \\
\hline & & & Means & STD. & Means & STD. & \\
\hline \multirow{9}{*}{$\begin{array}{l}\text { Pronunciations } \\
\text { Post }\end{array}$} & \multirow[t]{3}{*}{ Experimental } & Male & 12.29 & 2.289 & 21.71 & .756 & 7 \\
\hline & & Female & 13.29 & 2.289 & 22.43 & .976 & 7 \\
\hline & & Total & 12.79 & 2.259 & 22.07 & .917 & 14 \\
\hline & \multirow[t]{3}{*}{ Control } & Male & 12.29 & 1.113 & 18.29 & 1.890 & 7 \\
\hline & & Female & 13.00 & 1.309 & 19.00 & 1.690 & 8 \\
\hline & & Total & 12.67 & 1.234 & 18.67 & 1.759 & 15 \\
\hline & \multirow[t]{3}{*}{ Total } & Male & 12.29 & 1.729 & 20.00 & 2.253 & 14 \\
\hline & & Female & 13.13 & 1.767 & 20.60 & 2.230 & 15 \\
\hline & & Total & 12.72 & 1.771 & 20.31 & 2.222 & 29 \\
\hline \multirow[t]{9}{*}{ Abstraction Post } & \multirow[t]{3}{*}{ Experimental } & Male & 11.57 & 1.512 & 21.00 & 1.000 & 7 \\
\hline & & Female & 12.57 & 1.512 & 21.57 & .976 & 7 \\
\hline & & Total & 12.07 & 1.542 & 21.29 & .994 & 14 \\
\hline & \multirow[t]{3}{*}{ Control } & Male & 12.14 & 1.069 & 18.86 & 1.773 & 7 \\
\hline & & Female & 13.00 & 1.195 & 18.88 & 2.532 & 8 \\
\hline & & Total & 12.60 & 1.183 & 18.87 & 2.134 & 15 \\
\hline & \multirow[t]{3}{*}{ Total } & Male & 11.86 & 1.292 & 19.93 & 1.774 & 14 \\
\hline & & Female & 12.80 & 1.320 & 20.13 & 2.356 & 15 \\
\hline & & Total & 12.34 & 1.370 & 20.03 & 2.061 & 29 \\
\hline \multirow[t]{9}{*}{ Writing Post } & \multirow[t]{3}{*}{ Experimental } & Male & 9.86 & 1.069 & 19.86 & 1.574 & 7 \\
\hline & & Female & 10.57 & 1.134 & 20.43 & 1.718 & 7 \\
\hline & & Total & 10.21 & 1.122 & 20.14 & 1.610 & 14 \\
\hline & \multirow[t]{3}{*}{ Control } & Male & 10.71 & .951 & 17.29 & 1.604 & 7 \\
\hline & & Female & 11.25 & .707 & 17.00 & 2.330 & 8 \\
\hline & & Total & 11.00 & .845 & 17.13 & 1.959 & 15 \\
\hline & \multirow[t]{3}{*}{ Total } & Male & 10.29 & 1.069 & 18.57 & 2.027 & 14 \\
\hline & & Female & 10.93 & .961 & 18.60 & 2.667 & 15 \\
\hline & & Total & 10.62 & 1.049 & 18.59 & 2.338 & 29 \\
\hline
\end{tabular}

It is noticed from Table (8) that there are apparent differences between the arithmetic meanings in the pre and post measurements of the dimensions of the alphabet learning skills resulting from the difference of the group variables (experimental, control) and gender. This is as shown in Table (9) 
Table 9. Results of the Binary variance analysis accompanying multiple of the group's effect (experimental, control), gender, and the interaction between them on the dimensions of alphabet learning skills

\begin{tabular}{llllllll}
\hline Impact & $\begin{array}{l}\text { Kind of Binary } \\
\text { variance }\end{array}$ & $\begin{array}{l}\text { Value of Binary } \\
\text { variance }\end{array}$ & P-Value & $\begin{array}{l}\text { Default freedom } \\
\text { degree }\end{array}$ & $\begin{array}{l}\text { Freedom } \\
\text { degree }\end{array}$ & $\begin{array}{l}\text { Probability of } \\
\text { errors }\end{array}$ & $\begin{array}{l}\text { Impact size } \\
\boldsymbol{\eta} \mathbf{2}\end{array}$ \\
\hline Group & Hotelling's Trace & 2.281 & 15.204 & 3.000 & 20.000 & .000 & .695 \\
Gender & Hotelling's Trace & .139 & .928 & 3.000 & 20.000 & .445 & .122 \\
$\begin{array}{l}\text { Group* } \\
\text { Gender }\end{array}$ & Wilks' Lambda & .970 & .204 & 3.000 & 20.000 & .892 & .030 \\
\hline
\end{tabular}

Table (9) shows the presence of a statistically significant group effect at the level of significance $(\mathrm{a}=0.05)$ on the dimensional measurement of the dimensions of alphabet learning skills combined. As the Hotelling value was (2.281) and in statistical significance amounted to (0.000), there was no statistically significant effect for both gender and the interaction between the groups. To determine which dimension of the group effect was, the accompanying bilateral analysis of variance (ANCOVA) was performed for each dimension after neutralizing the effect of the pre-measurement they have, as shown in Table (10):

Table 10. An analysis of the accompanying binary variance (ANCOVA) for the effect of the group and the gender and the interaction between them on the dimensional measurement of each dimension of the alphabet learning skills after neutralizing the effect of the pre-measurement they have

\begin{tabular}{|c|c|c|c|c|c|c|c|}
\hline $\begin{array}{l}\text { Source of } \\
\text { variance }\end{array}$ & & $\begin{array}{l}\text { sum of } \\
\text { squares }\end{array}$ & $\begin{array}{l}\text { degree } \\
\text { of } \\
\text { freedom }\end{array}$ & $\begin{array}{l}\text { mean of } \\
\text { the sum of } \\
\text { squares }\end{array}$ & P. Value & $\begin{array}{l}\text { probability } \\
\text { of error }\end{array}$ & $\begin{array}{l}\text { size of } \\
\text { effect } \eta 2\end{array}$ \\
\hline \multirow[t]{3}{*}{$\begin{array}{l}\text { Pronunciation } \\
\text { Pretest }\end{array}$} & $\begin{array}{l}\text { Pronunciation } \\
\text { Post-test }\end{array}$ & 1.965 & 1 & 1.965 & .903 & .352 & .039 \\
\hline & $\begin{array}{l}\text { Abstraction Post- } \\
\text { test }\end{array}$ & .551 & 1 & .551 & .439 & .514 & .020 \\
\hline & $\begin{array}{l}\text { Writing } \\
\text { Post- test }\end{array}$ & .803 & 1 & .803 & .225 & .640 & .010 \\
\hline \multirow[t]{3}{*}{$\begin{array}{l}\text { Abstraction } \\
\text { Pre-test }\end{array}$} & $\begin{array}{l}\text { Pronunciation } \\
\text { Post- test }\end{array}$ & .088 & 1 & .088 & .041 & .842 & .002 \\
\hline & $\begin{array}{l}\text { Abstraction } \\
\text { Post-test }\end{array}$ & 11.734 & 1 & 11.734 & 9.360 & .006 & .298 \\
\hline & $\begin{array}{l}\text { Writing } \\
\text { Post- test }\end{array}$ & .099 & 1 & .099 & .028 & .869 & .001 \\
\hline \multirow[t]{3}{*}{ Writing Pre-test } & $\begin{array}{l}\text { Pronunciation } \\
\text { Post- test }\end{array}$ & .140 & 1 & .140 & .064 & .802 & .003 \\
\hline & $\begin{array}{l}\text { Abstraction } \\
\text { Post-test }\end{array}$ & 31.186 & 1 & 31.186 & 24.876 & .000 & .531 \\
\hline & $\begin{array}{l}\text { Writing } \\
\text { Post- test }\end{array}$ & .813 & 1 & .813 & .227 & .638 & .010 \\
\hline \multirow[t]{3}{*}{ Group } & $\begin{array}{l}\text { Pronunciation } \\
\text { Post- test }\end{array}$ & 54.607 & 1 & 54.607 & 25.097 & .000 & .533 \\
\hline & $\begin{array}{l}\text { Abstraction } \\
\text { Post-test }\end{array}$ & 54.106 & 1 & 54.106 & 43.158 & .000 & .662 \\
\hline & $\begin{array}{l}\text { Writing } \\
\text { Post-test }\end{array}$ & 52.128 & 1 & 52.128 & 14.588 & .001 & .399 \\
\hline \multirow[t]{2}{*}{ Gender } & $\begin{array}{l}\text { Pronunciation } \\
\text { Post-test }\end{array}$ & 2.445 & 1 & 2.445 & 1.124 & .301 & .049 \\
\hline & Abstraction Post- & .142 & 1 & .142 & .113 & .740 & .005 \\
\hline
\end{tabular}




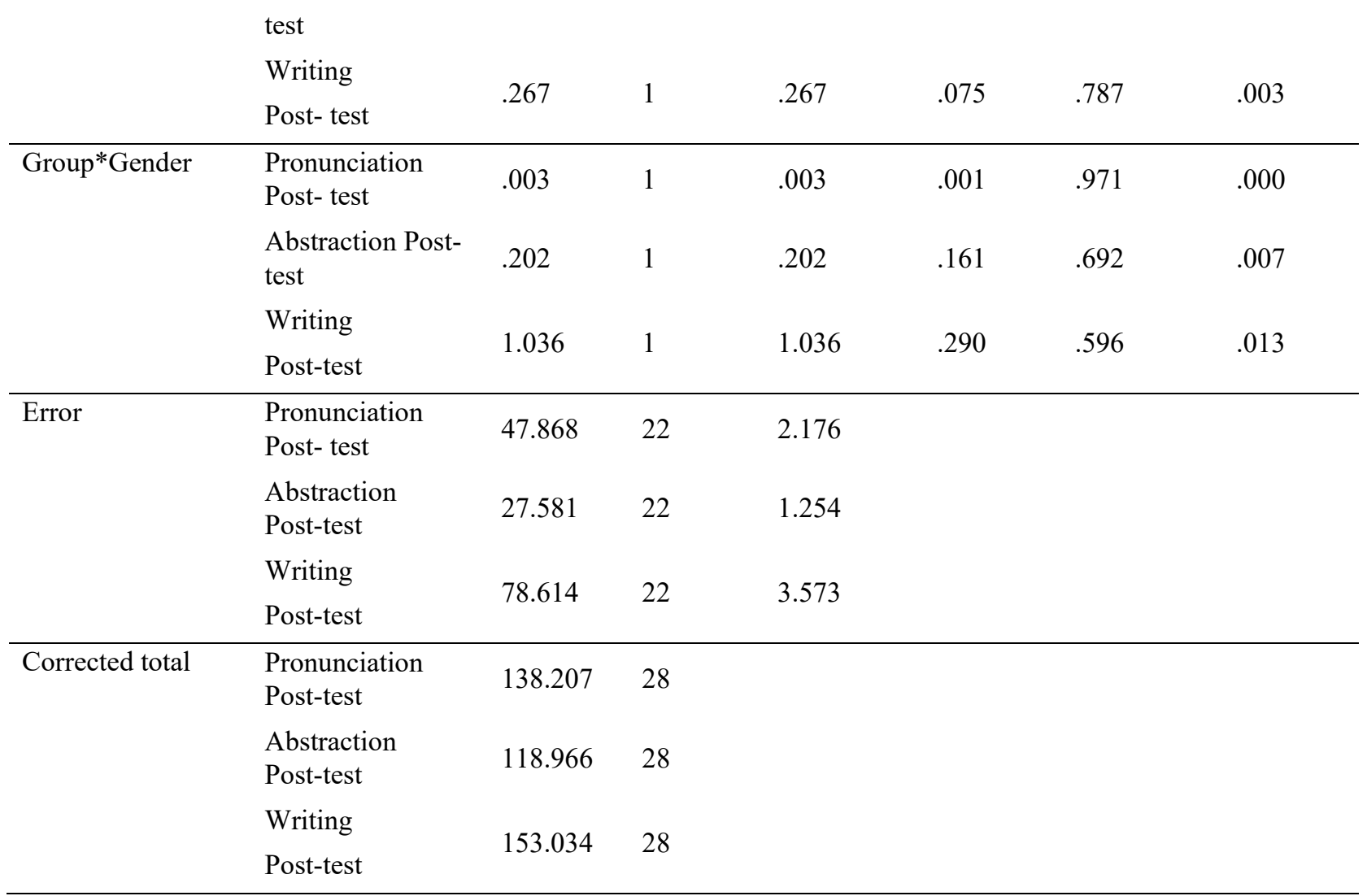

Table (10) shows that there are statistically significant differences at the level of significance $(\alpha=0.05)$ according to the group's effect (experimental, control) in all dimensions. To determine in favor of which of the two study groups were the essential differences, the adjusted arithmetic averages and standard errors of the dimensions were calculated according to the group, as shown in Table (11).

Table 11. The modified arithmetic means and standard errors for post-measurement of the dimensions of the alphabet learning skills according to the group

\begin{tabular}{llll}
\hline & Group & modified arithmetic mean & STD. \\
\hline Pronunciation & Experimental & 21.997 & .437 \\
Post-test & Control & 18.715 & .418 \\
Abstraction & Experimental & 21.730 & .331 \\
Post-test & Control & 18.463 & .317 \\
Writing & Experimental & 20.255 & .560 \\
Post-test & Control & 17.048 & .536
\end{tabular}

It is evident from Table (11) that the essential differences between the arithmetic meanings modified for dimensional measurement in all dimensions of alphabet learning skills were in favor of the members of the experimental group who were exposed to the digital educational story compared to the control group members, noting that the effect size of the dimensions was large, and ranged between (39.9\%)-(66.2\%).

\section{Result Discussion}

Education is the making of the present and the future, it is the process of building people, and education is a basic and important entrance to society's reform, development, and progress.

If this is visible in the developed world, it is urgently needed in developing countries seeking to catch up with the developed world. It is in dire need to take education as an entry point to reform and modernize society, and that is from the beginning that concern for the child as a human being has the right to enjoy the current stage in his development, live in safety and fun, and develop his potentials and abilities. This lofty goal comes before the goal is to prepare the child for the development of society. 
The study results showed that there are statistically significant differences attributed to employing the digital story based on sport in developing alphabet skills combined in each of the skills: (pronunciation, abstraction, and writing); perhaps this is due to the advantage of digital stories. As it is a sophisticated type that keeps pace with innovative technology, especially in directing, stories contain the element of sound, image, and movement; Also, these stories are instruction in their content, and their topic deals with the alphabet. These results may also be attributed to these stories' characteristics, such as attracting attention, positivity in learning, and simulated reality.

This confirms what Al-Mestarihi (2013) pointed out: the stories used in education work to increase positive participation, develop linguistic vocabulary, and reading comprehension among young people. The results in this study are consistent in emphasizing the effectiveness of using stories in teaching Arabic, with the results of (Loniza et al., 2018), which confirmed the effectiveness of using stories in developing listening comprehension skills in early childhood. Al-Areenan study (2015), which confirmed the effectiveness of using electronic stories in developing some language skills such as listening and speaking in a kindergarten child, the study of (Al-Juhani, 2015), showed the existence of differences in the strategy of storytelling in developing listening comprehension skills, and a study (Soleimani \& Akbari, 2013), which showed the existence of an impact of storytelling on kids' vocabulary learning in the English language.

As for the superiority in the skill of pronunciation, the reasons for this may be attributed to the fact that the digital stories provided the possibility for the child to see the letter in sound and image in an interesting way, the method of producing the sound corresponded to his age and mental level supported by examples pronouncing the letter, coupled with the image and the pronunciation of the word; The kids were able to correctly pronounce the letters and remove them from their exits, as the digital stories displayed the letters in their various forms accompanying the movements, and the teacher's role in the processes of kids's repetition of the letter accompanied by the smart screen, and by individual and collective learning methods at times, and at other times with the child watching him had an effect Effective in showing differences; This led to pre-school kids possessing the skills of pronouncing letters from their exits properly, pronouncing the letter with the accompanying movements, and pronouncing the syllables of letters correctly and without errors, the words repetition attentively to the sound of the letter in given words, and this corresponds to what was confirmed by (Frazel, 2010) that stories improve the pronunciation of letters with the accompanying movements from their exits in a sound manner, and that they work to enrich and develop spoken language. Speaking to a kindergarten child, including Mastering the skills of pronouncing letters expressing words correctly, and with the results of the study of (Yaghmour \& Obaidat, 2016) which confirmed the effect of using the method of storytelling in developing the skill of reading in the aspect of taking the letters out of their exits and pronouncing the words correctly.

As for the students' superiority in the skill of abstraction, the reasons may be due to the kids' understanding of the educational story that is characterized by excitement. It presents vocabulary related to animals and plants; kids can interact with it, see letter syllables through it, and practice synthesis and analysis processes accompanied by digital stories that covered this aspect using various language learning processes. As the digital stories were targeted, they dealt with indicators of the skill of abstraction; The kids were able to master these indicators, such as: knowing the required letter within a particular word, analyzing words that contain an alphabet into syllables, the composition of syllables from the letters of the words. The results in this study are consistent with the results of (Soleimani \& Akbari, 2013) that showed the effect of narration stories on learning kids' vocabulary in English, and the results of (Yaghmour \& Obaidat, 2016), which confirmed the effect of using storytelling method on developing the skill of acquiring the ability to understand and distinguish letters, and to perform analysis and synthesis processes.

In terms of pre-school kids' superiority in writing, the reasons may be attributed to digital stories' focus on addressing issues related to writing, dictation, and copying. The stories included in their design these things to improve them among pre-school kids; perhaps this was also due to the teacher's practices during the presentation of the educational story as she was framing the smart screen and instructing pre-school kids to come out and write the letter, according to what they saw in the educational story.

According to the typical performance provided by the Arabic language teacher, as well as the digital stories displaying the alphabet, a proper spelling mechanism, and accompanying the pronunciation process, which led to the mastery of this skill as well as the accompanying activities to teach the skill in kids' notebooks, this led to the skills of passing the pen over the specific letter, coloring the blank representing a specific letter, filling the space in the appropriate letter shape, and rewriting the letter in beautiful handwriting. These results are consistent with the results (Yamac \& Ulusoy, 2016), which emphasized that digital storytelling contributes to improving learners' writing skills. 
The results showed no statistically significant differences attributed to gender and interaction, which indicates that pre-school kids interacted with digital stories at the same level. Perhaps this is due to the kids' quality, their educational environments, and the similarity of their cultural and social levels. Also, the kids were subjected to the same treatment and from one teacher, and in light of the similar spatial and temporal conditions, which led to the cancellation of the significance of these differences.

This result, concerning gender, contrasts with the study oftoto (Yaghmour \& Obaidat, 2016), in which the results were in favor of males; this was attributed to the ability of males to remember information, keep it, and pay attention to educational attitudes, accuracy, follow-up, and an atmosphere of competition more than females. This increased their motivation towards learning and showed the significance of the differences. As for interaction, the study results agreed with (Yaghmour \& Obaidat, 2016) for reasons related to learning conditions, teaching method, and study variables that canceled the significance of the differences.

\subsection{Recommendations}

In light of the findings of the study, the researchers recommend the following:

1) Include Arabic language curricula guides in digital educational programs based on sports to be used in Arabic teaching processes.

2) Holding training courses for Arabic language teachers to inform them of the importance of employing digital technologies in teaching the Arabic language

3) Conducting research and studies dealing with the impact of digital educational programs based on sports on teaching Arabic language skills and systems.

\section{References}

Abu Afifa, Haya. (2016). The effect of teaching the Arabic language using a digital story for the third grade in developing active listening and creative thinking skills. Unpublished Master Thesis, Middle East University, Jordan.

Abu Jamous, Abd al-Karim, \& Canaan Eid. (2008). The kinetic story's effect on developing some linguistic patterns and motor performances among kids of the first year of basic education in Jordan. An-Najah University Journal for Research (Humanities), 22(5), 1567-1597.

Abu Latifa, Raed. (2009). Developing language skills for kindergarten kids. Arab Society Library for Publishing and Distribution: Amman.

Abu Sakran, M. (2017). Effectiveness of proposed program based on mathematical power in developing achievement, divergent thinking, and mathematical communication among tenth-grade students. Unpublished Doctoral Dissertation, Ain Shams University, Egypt.

Ahmed, Samir. (2004). Kids' stories and tales and their practical applications. Amman: House of the March for Publishing and Distribution.

Al-Areenan, Hadeel. (2015). The Effectiveness of Using E-Story in developing Some Language Skills of Kindergarten Kids. Unpublished Master Thesis, Umm Al-Qura University, Saudi Arabia.

Al-Ghamdi, Saeed. (2013). An educational bag's effectiveness in providing the skill of distinguishing between similar Arabic alphabets in pronunciation and writing for first-grade pupils. Unpublished Master Thesis, Al-Baha University, Saudi Arabia.

Al-Juhani, Abdullah. (2015). The Impact of Story-Telling Strategy on the Development of Listening Comprehension Skills for Second-Grade Students in Saudi Arabia. The International Journal of Specialized Education, 30(1), 187-202.

Al-Khatib, Muhammad. (2009). Curricula and methods of teaching the Arabic language in the basic education stage. Amman: Al-Warraq Foundation.

Al-Mestarihi, Hussein. (2013). The two narrow and selective reading strategies improve vocabulary learning and reading comprehension among the eighth-grade students in Jordan. Unpublished Ph.D. thesis, Yarmouk University, Jordan.

Ashour Ratib, \& Miqdadi, Fakhry. (2005). Reading and writing skills, teaching methods, and strategies. Amman: House of the March.

Frazel, M. (2010). Digital storytelling: Guide for educators. Eugene, OR: International Society for Technology in Education (ISTE). 
Hett, K. (2012). Technology-supported literacy in the classroom: Using audiobooks and digital storytelling to enhance literacy instruction. Illinois Reading Council Journal, 40(3), 3-13.

Lee, L. (2014). Digital New Stories: Building Language Learners' Content Knowledge and Speaking Skills. Foreign Language Annals, 77(2), 338-356. https://doi.org/10.1111/flan.12084

Loniza, A., Saad, A., \& Mustafa, M. (2018). The Effectiveness of Digital Storytelling language listening comprehension of Kindergarten pupils. The International Journal of Multimedia \& Its Applications (IJMA), 10(6), 131-140. https://doi.org/10.5121/ijma.2018.10611

Miller, J., (2015). Digital Storytelling as an Integrated Approach to Second Language Learning and Teaching. Untested Ideas Research Center, 4(3-4), 41-55.

Shelton, A., \& Hale, A. E. (2017). Bringing Digital Storytelling to the Elementary Classroom: Video Production for PR service Teachers. Journal of Digital Learning in Teacher Education, 33(2), 58-68. https://doi.org/10.1080/21532974.2016.1276871

Slot, Faten. (2010). The effect of employing educational games in distinguishing between similarly shaped and pronounced letters of second-grade students. Published Master Thesis, Gaza University, Palestine.

Soleimani, H., \& Akbari, M. (2013). The Effect of Storytelling on Kids' Learning English Vocabulary: A Case in Iran. International Research Journal of Applied and Basic Sciences, 5(1), 104-113.

Soman, Ahmad. (2012). Methods of teaching the Arabic language. Amman: Zahran House.

Yaghmour Kholoud, \& Obaidat Luay. (2016). The role of storytelling style in developing the reading skill of first-graders in the education of Bani Kinana. An-Najah University Journal for Research (Humanities), 30(9), 1878-1896.

Yamac, A., \& Ulusoy, M. (2016). The Effect of Digital Storytelling in Improving the Third Graders' Writing Skills. International Electronic Journal of Elementary Education, September, 9(1), 59-86.

Zahran Hamed, \& Taaima Rushdie. (2009). Kids' linguistic concepts: foundations, skills, and evaluation. Amman: House of the March.

Zankour, M. (2017). The Digital Story in Mathematics for Developing Mathematical Imagination and Numerical Intelligence among Primary School (Impulsive / Reflective) Students. Journal of Educational Mathematics, 20(5), 1-129. https://doi.org/10.21608/armin.2017.81630

\section{Copyrights}

Copyright for this article is retained by the author(s), with first publication rights granted to the journal.

This is an open-access article distributed under the terms and conditions of the Creative Commons Attribution license (http://creativecommons.org/licenses/by/4.0/). 